\title{
Rethinking settlements in arid environments: case study from Uzbekistan
}

\author{
Akmal Karimov ${ }^{1}$, Abdulkhakim Salokhiddinov ${ }^{1 *}$, Inna Gracheva ${ }^{2}$, Ravshan Umurzakov ${ }^{1}$ \\ and Qadyr Artykov ${ }^{2}$ \\ ${ }^{1}$ Tashkent Institute of Irrigation and Mechanization of Agriculture Engineers, Uzbekistan, 39, Qori \\ Niaziy, Tashkent,100000, Uzbekistan \\ ${ }^{2}$ State Unitary Enterprise Uzbekhydrogeology, 64, Olimlar str., Tashkent,100041, Uzbekistan
}

\begin{abstract}
Fast growing population of Uzbekistan and increasing the share of urban citizens increased inter-linkages between settlements and irrigated farming. Growing settlements on account of farm land, increasing the demand for high quality water, wastewater utilization in agriculture, water logging and salinization are some of the water related inter-linkages. This paper focus on waterlogging issue at three different sites, located in the upstream of the Syrdarya River in Fergana Valley, middle stream of river in Mirzachul Steppe and the downstream of Amudarya River in Khorezm region. Groundwater modeling applied to examine different strategies of to lower shallow groundwater table. The results of the modeling studies indicate that ultimate solution for waterlogging issue can be achieved when basin water management plans linked with settlement development plans.
\end{abstract}

\section{Introduction}

Settlements and irrigated farming, the two main attributes of arid and semi-arid environments, are involved in many interactions and inter-linkages with potential positive and negative consequences. Advance consideration of these externalities may contribute to sustainable development of the both and regions as a whole [1,2]. The aim of this paper is twofold: (1) bringing the attention of urban and rural area developers to close examination of water related issues arising through these interactions, and; (2) examining alternative strategies to avoid waterlogging.

Expansion of urban areas starts to impinge on the quality of water available for agriculture [3], at the same time irrigated farming limits water resources available for the domestic use and the industrial development. Another often invisible impact of irrigated farming is associated with raising the groundwater table in urban and semi-urban areas. In China 351 cities, in Kyrgyz Republic 215 settlements and in Uzbekistan 78 cities and towns are waterlogged [4,6]. Ning [6] examined waterlogging of cities in China and concluded that the project focusing on the construction of large scale storage tanks, pumping stations, improving the drainage network do not investigate the corresponding conditions conducive

\footnotetext{
* Corresponding author: pepiwm@gmail.com
} 
to waterlogging. Reed et. al. [7] applied a "shared learning approach" in 10 cities of Vietnam, India and Thailand and Indonesia found a clear linkage between waterlogging and poor flood water management. Sharma et al. [8] indicated significant economic losses suffered by the urban poor due to climate-induced waterlogging in the city of Indore, India [9]. Water logging of settlements is indicated in Egypt, and Russia [10,11]. According to Medvedkov and Stripling [10] about $75 \%$ of cities and over $20 \%$ of small settlements in Russia are waterlogged. In spite of significant attention, the issue is one of many constrains complicating the development of urban areas in many parts of the arid and semi-arid regions. The attempts of installing the drainage network to lower the groundwater table and protecting the settlements often fail to solve the issue. The paper examines alternative strategies to deal with waterlogging for three different agro-ecological conditions of Uzbekistan, Central Asia.

\section{Settlements vs. irrigated farming}

A main driving force of settlements development in Uzbekistan is the fast growth of the population. From 20 million $(\mathrm{mln})$ in 1990, of which 59\% was rural, the population reached to $32 \mathrm{mln}$ in 2017 with $49 \%$ in rural areas [12]. The significant part, $40 \%$, of the population lives these days in the cities with inhabitants over 100000. Such dramatic changes have considerable impacts on the farming and the environment. These impacts include: growing settlements on account of farm land; increasing the demand for high quality water and the discharge of 'treated' and untreated wastewater, water logging and salinization. Water management is under the pressure to respond to the growing challenges.

Meeting the growing demand is constrained by limited water resources. Potential water resources available for use in Uzbekistan have been gradually reducing from $57 \mathrm{~km}^{3}$ in 1990s to $51 \mathrm{~km}^{3}$ by 2017 due to increasing the number of low water years, the upstream hydropower development and climate change [13]. Water availability per capita is reduced from $2800 \mathrm{~m}^{3}$ per year in 1990 to $1545 \mathrm{~m}^{3}$ per year by 2017. Climate change may further reduce the available water resources - by $10-15 \%$ to 2050 in Amudarya River basin and 2$5 \%$ in Syrdarya River basin [13].

These limited water resources are shared among several types of water uses. Sector vice, $92 \%$ of water available is used for irrigation purposes, $5.2 \%$ for domestic and $1.5 \%$ for industrial purposes, $0.8 \%$ for fishery and $0.2 \%$ for energy.

Growing domestic and industrial water demand can be satisfied by re-allocating water from agriculture and using the marginal quality water originating in urban and rural areas. A coarse estimates show that the amount of domestic and industrial wastewater exceeds 2 $\mathrm{km}^{3} /$ year. This data shows that water resources are available, however, they have to be managed properly to ensure sustainable development of settlements and the irrigated farming.

These inter-linkages gradually become the most critical water-related challenge with long term negative and positive impacts. Discharging the 'treated' wastewater to canals causing the degradation of water quality in irrigation water sources and growing settlements on account of the productive agricultural land are the two main negative impacts of the settlements. The positive outcome is that; peri-urban agriculture has become the important source of residents' income in many urban areas of Uzbekistan. For example, majority of citizens of Altyaryk town in Fergana Valley produce annually over $1 \mathrm{t}$ of grapes from their small backyards. During winter season greenhouses covering the shortage of vegetables in city markets make significant contribution to the income of inhabitants of peri-urban and rural areas. 
Another opportunity is associated with establishing multifunctional parks - buffer zones between cities and farm lands to improve living environments in urban areas. With some modifications such parks can be used for utilizing the domestic treated wastewater. In saltaffected areas, these buffer zones may be used for utilizing the drainage flow from the irrigated land. Closed loop agricultural water management can prevent crossing the settlements by drainage network [14].

The irrigated farming also may have undesirable impacts on settlements. Invisible for the time being, raising the groundwater table causes waterlogging, deteriorates landscapes and increases secondary salinization of residential areas. Waterlogging of settlements was the main focus of this study.

Number of settlements by provinces, as affected by water logging, is given in Fig. 1 (Umurzakov, pers. commun., 2019). Fig. 1 shows that the settlements of Syrdarya, Kashkadarya, Fergana and Bukhara provinces are highly affected by water logging. Causes of water logging include: lateral inflows from the irrigated areas; high filtration losses from canals crossing the settlements; barriers to groundwater flow - foundation of constructions; embankments for roads and railways, and; natural hydrogeology conditions.

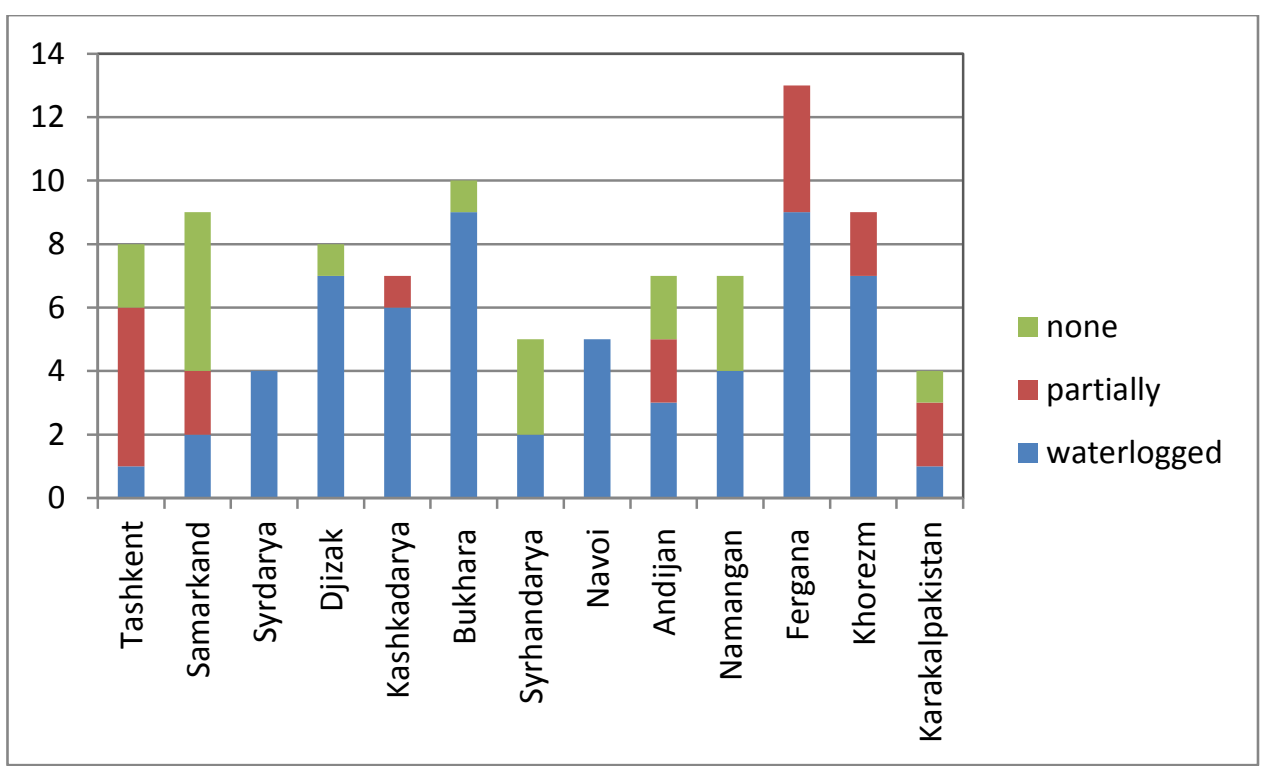

Fig. 1. Number of waterlogged cities in province of Uzbekistan and in Karakalpakistan (Umurzakov, pers.commun., 2019)

Waterlogging produces long term impacts on settlements, such as flooding the basements, and weakening the foundations, evaporation from shallow water table resulting in salinization of the residential areas [15]. It reduces job opportunities and increases the water shortage. This way waterlogging increases a risk of migration from rural areas to small towns and from towns of 50,000-100,000 residents to bigger cities and the capital.

The attempts of city administrations to install the drainage network in several waterlogged settlements of Uzbekistan did show that this approach often is not cost effective. This experience indicates the needs of examining alternative strategies in different hydrogeological conditions to mainstream appropriate into urban and water resources development plans. 


\section{Methods and data}

\subsection{Waterlogging in Sokh River basin}

Waterlogging is associated with Sokh Aquifer, underlying the river basin [16,17]. The aquifer spread in primarily unconsolidated shingle and gravel outwash deposits with interlayers of loamy sand and loamy deposits. The gravel and shingle deposits predominate in the upper part in the south of the study area with increasing the proportions of loamy sand and loamy deposits in the downstream in the northern part. The depth to access groundwater varies from $72 \mathrm{~m}$ to $116 \mathrm{~m}$ in the head part of the system and can be as little as 0.5-2.5 m below ground level in the discharge zone. Big Fergana Canal crosses the river basin from east to west and supplies water to the water short areas of the Fergana Valley.

Several cities in the river basin (Kokand, Rishtan, Bagdad) are waterlogged due to the upstream subsurface flow, filtration from wide spread irrigation canals and infiltration from the irrigated fields [18]. This study analyzed alternative strategies to lower the water table in the city areas as follows:

Strategy 1. Installing rows of wells and open drainage network perpendicular to the subsurface flow from the upstream of the Sokh River and within the cities (city administration approach);

Strategy 2: installing wells for irrigation and shift from canal irrigation to conjunctive use of canal and groundwater for irrigation (farmers approach).

Two selected strategies were analyzed to achieve water logging effect and financial reliability.

\subsection{Waterlogging of Gulistan city}

The city is located in the middle of Mirzachul steppe on the right bank of Syrdarya River midstream. Interstate canal Dustyk starting from Syrdarya River at Farhad Dam crosses the city from south to north [19]. Hydrogeological cross section at the city site is represented by heavy loams and loams of 21-29 m thick with coefficient of filtration varying from 0.03 $0.08 \mathrm{~m} / \mathrm{s}$ followed by sand of $10-25 \mathrm{~m}$ with the coefficient of filtration of $35 \mathrm{~m} / \mathrm{s}$. Water losses from the irrigated fields surrounding the city and the regional flow from the south to the north causes water table rise and waterlogging issue in the city. Groundwater table fluctuates between seasons and is high during the spring and lower in the summer. In spring water table is $1-1.5 \mathrm{~m}$ deep below the ground. Then in summer water table declines due high evaporation and stabilizes at $2 \mathrm{~m}$ below the ground in October. Waterlogging in the city produces long term impacts such as flooding the basements and salinization of the residential areas.

Modeling was applied to examine waterlogging as affected by two alternative interventions:

Scenario 1: The construction of wells within the city and drainage along the canal Dustyk; Scenario 2: Reducing infiltration losses by improving city irrigation. Visual MODFLOW was used to predict groundwater level changes under scenarios 1 and 2.

\subsection{Waterlogging of Urgench city, Khorezm region}

The city Urgench is located in Khorezm region in the ancient delta of Amudarya. The territory is flat, unlined irrigation canals are the main source of groundwater recharge [20]. Canal Shavat crossing the city delivers water of Amudarya River for irrigation of 112,000 
ha area. The discharge of the canal is $210 \mathrm{~m}^{3} / \mathrm{s}$. The hydrogeological cross section at the city site is represented by loams of 1-3 m thick with coefficient of filtration at $0.5 \mathrm{~m} / \mathrm{s}$; sand deposits of 25-35 m thick with the coefficient of filtration from 7-15 m/s underlay loams. Presence of highly permeable sands in the soil profile forms high correlation between the water level in the canal and groundwater table under the city.

Modeling was applied to examine waterlogging as affected by two alternative strategies:

Strategy 1: The construction of drainage ditches to lower groundwater level;

Strategy 2: The construction of drainage ditches and installing wells to lower the water table.

Visual MODFLOW was used to predict groundwater level changes under scenarios 1 and 2.

\section{Results}

\subsection{Waterlogging in Sokh River basin}

The first strategy is narrow oriented, often supported by donors(WorldBank); this is the attempt to dealing with the consequences rather than with the roots of the problem which in this case is wide spread earth' irrigation canals and conventional furrow irrigation in the river basin. Another issue associated with the strategy is to determine who pays for the investments. City administrations have no enough resources for new investments. Transferring lifted water to water user associates located in the neighboring river basin will not generate additional income since water for irrigation is free. The interest of private business to make investments in fighting the waterlogging is low since it may generate low returns in short run from as compared to other financial operations. The economic return from the investment in waterlogging of cities is expected to be only from the benefiting residents, paying $\$ 0.08 \mathrm{US} / \mathrm{m}^{3}$. The residents hardly will agree pay back the investment. These analyses do show that under current free water delivery services there is no pay back mechanism under which the investors can collect the payment from the beneficiaries.

The second strategy deals with the roots of the problem; it takes into account that Fergana Valley has favorable conditions to increase groundwater abstraction for irrigation with a net reduction of drainage and subsurface flows from the irrigation areas (Borisov, 2000). Wells can be installed at locations meeting needs of farmers. Farmers owning wells will have more incentives to pay back for the investments. The shift from canal irrigation to conjunctive use of canal and ground water can generate several benefits for the state and the farmers:

- Increasing the groundwater abstractions can lower the water table;

- Water productivity under groundwater irrigation is higher than under canal irrigation;

- Underground storages can be used for regulating surface and subsurface flows;

- Easy applying water-saving micro-irrigation technologies;

- Easy introducing economic instruments for water saving such water use pricing.

The state will transfer the assets such as wells, water saving technologies or facilities installed through the investment projects to farmers. Farmers' willingness to pay back the state investments expected to be high since they are main beneficiaries of the investments.Examining Strategy 2 shows that ultimate solution to water logging of settlements is improved water management.

\subsection{Waterlogging of Gulistan city}

Estimates using Visual MODLOFW did show that the canal does not make significant contribution to groundwater recharge because of low permeable soil top-layer represented 
by heavy loams. The construction of the drainage system along the canal under scenario 1 was found to be inefficient for the same reason (Fig. 2).

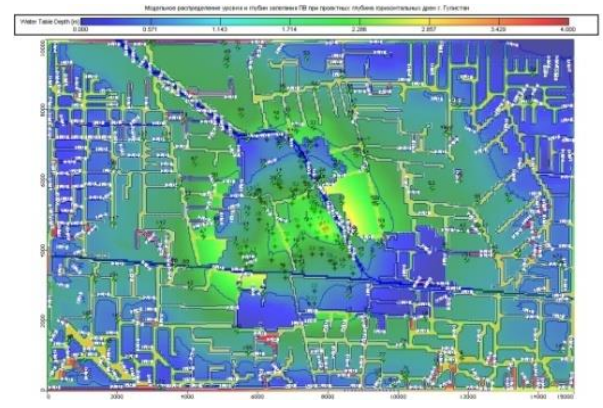

a)

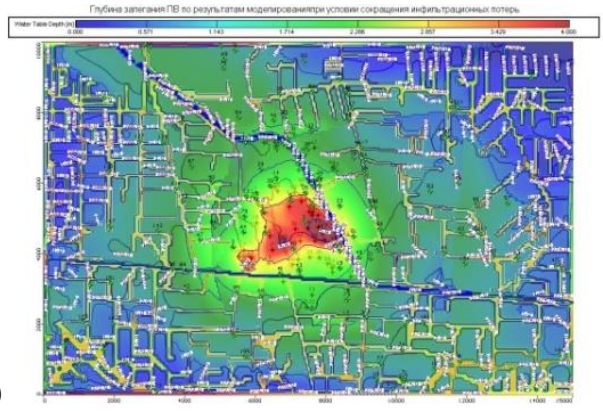

b)

Fig.2. Modeled groundwater depths as affected by installing drainage ditches (a) and reducing infiltration losses (b)in Gulistan city.

The modeling results indicate that measures aimed reducing infiltration losses within the city/residential area are the most efficient method to deal with waterlogging. These measures include: installing water harvesting structures; shifting from surface irrigation to micro-irrigation technologies for irrigation of tree plantations.

\subsection{Waterlogging of Urgench city, Khorezm region}

Modeling results given in Fig. 3 and 4 indicate that the examined strategies lowered the groundwater table in some districts of the city.

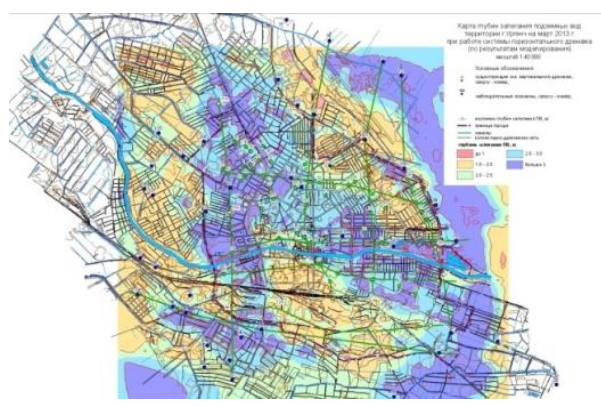

a)

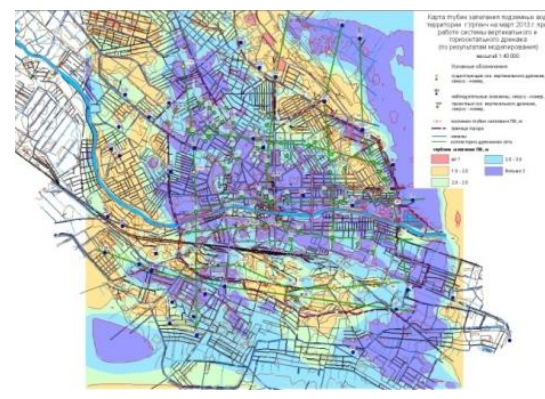

b)

Fig. 3. Modeled groundwater depths as affected by combination of groundwater extraction and drainage (a) and installing drainage, only (b)

The problem solution came from the city administration which built a recreation lake in the lowest part of the city surrounded by green zone with tree plantations.

Findings of the studies are as follows:

- Depending on soil and hydrogeology conditions different alternatives are available to lower the shallow water table;

- The shift where possible from canal irrigation to conjunctive use of groundwater and canal water can solve water logging issue of settlements;

- If soil profile is represented by heavy loam soils underlay by sand and gravel deposits then reducing infiltration losses by water harvesting, installing micro-irrigation for landscape, tree shelterbelts or crop irrigation may be a best settlement strategy; 
- If soil profile is represented by sand and sandy loams then lining canals crossing the settlements and adopting settlements architecture (lakes, parks, recreation zones) could be considered to adopt to waterlogging negative consequences.

\section{Conclusions}

Based on the results of the studies, the conclusions are as follows:

1. City authorities and irrigation/farming management can take joint actions for eliminating the negative impacts to each other.

2. Best results are achieved when basin water management plans are linked with regional/city/settlement development plans.

3. Combination of basin scale measures and city actions can contribute to formation of sound living environments.

\section{References}

1. E. Glaeser, A. Joshi-Ghani. Rethinking Cities: Toward Shared Prosperity. Economic premise. The World Bank. (2013), N. 126, 14 p.

2. H. Cindric, J. Frost, T. Armour, A. McGregor. Cities alive: Rethinking cities in arid environments. ARUP. (2018). 140 p.

https://www.preventionweb.net/publications/view/57566

3. F. Molle, J. Berkoff. National Research Forum: United Nations Sustainable Development Journal. Cities vs. agriculture: A review of intersectoral water reallocation. Vol.33, Is.1. Special Issue: Integrated Water Resources Management in Water-Stressed Countries, (2009), p. 6-18.

4. N.M.Kim. Current status of soil and groundwater of Chui valley, its ecological and social pressure and forecast for 2020. (2013) $10 \mathrm{p}$.

5. Mambetov A. Disaster Risk Reduction in the Kyrgyz Republic. (2015). https://docplayer.ru/41325750-Snizhenie-riskov-bedstviy-v-kyrgyzskoy-respublikedokladchik-azamat-mambetov-zamestitel-nachalnika-cuks-mchs-kr.html

6. Y.-F. Ning, W.-Y. Dong, L.-S. Lin, Q. Zhang. Analyzing the causes of urban waterlogging and sponge city technology in China. (2017). https://iopscience.iop.org/article/10.1088/1755-1315/59/1/012047/pdf

7. S.O. Reed, R. Friend, V. Toan, P. Thinphanga, R. Sutarto, D. Singh. "Shared learning" for building urban climate resilience - experiences from Asian cities. (2013). https://journals.sagepub.com/doi/pdf/10.1177/0956247813501136

8. Sharma P., Karath A., Burvey M., Dubey A. The economic impact of floods and waterlogging on low-income households.Lessons from Indore, India. Asian Cities Climate Resilience. (2016). Working paper series 38, 31 p.

9. Gulab. 2014. Impact of water logging and salinity on agriculture and socio-economic status in Rohtar and Jharrar district. International journal for research in applied science and engineering technology (IJRASET). Vol. 2 Issue IV, April 2014. ISSN: 2321-9653. www.ijraset.com

10. S. Abdel-Dayem. Drainage experiences in arid and semi-arid regions. (2000). http://siteresources.worldbank.org/INTARD/8644771111647176321/20431949/Aridexperience.pdf

11. K.C. Medvedkov, L.O. Shtoppling Analysis of the flooded area on the example of groundwater of the city of Nazyvaevsk. News of Tomsk Polytechnic University. Georesource engineering. (2017). T.328. N 4, 85-93. 
12. State Committee of the Republic of Uzbekistan on statistics. Demographic situation. (2018). Tashkent. https://stat.uz/uploads/docs/Demografiya-yan-iyun-18-RU.pdf

13. M. Punkari, P. Droogers, W. Immerzee, N. Korhonen, A. Lutz, A. Venalainen. Climate change and sustainable water management in Central Asia. ADB Central and West Asia working paper series. (2014). 27p.

14. S. Sh. Mirzaev. D. M. Mamatkanov. Cononcept for preserving and restoring the aral sea and normalizing the ecological, public health, and socioeconomic situation in the Aral region, Post-Soviet Geography, (1992). 33:5, 283-

295, DOI: 10.1080/10605851.1992.10640901

15. D.K. Begimkulov. Regularities of formation of the process of flooding of urban areas. Materials of the Republican scientific and technical conference: Problems, development and innovative directions of geological Sciences in Uzbekistan (17 декабрь, 2013). Tashkent: TashGTU, (2013), p.220-222.

16. S.Sh. Mirzaev, A.Kh. Karimov. Basics of conjunctive use of underground and surface water for irrigation (in Russian). (1989). Tashkent: Fan. 100 p.

17. V.A. Borisov. Resources of underground waters and their use in national economy. Case of Uzbekistan. (1990). Tashkent: Fan. 142 p.

18. World Bank. Ferghana valley water resources management phase-I project. (2009). Report No: 49393-UZ. 99 p. http://pubdocs.worldbank.org/en/467111477882687735/090716-DRMSeminar13AzamatMambetov-RU.pdf

19. M.A. Ziyaeva Evaluation of the hydrogeological conditions of the Gulistan city and the forecast of their changes. (2016). Tashkent: TashGTU. 90 p.

20. The World Bank. South Karakalpakstan water resources management improvement Project. Environmental assessment and management plan. (2013). 116 p. http://documents.worldbank.org/curated/en/317111468173048196/pdf/E41550V20REV IS00Box385217B00PU BLIC0.pdf 